\title{
雌家鬼外尿道括約筋の生化学的検討
}

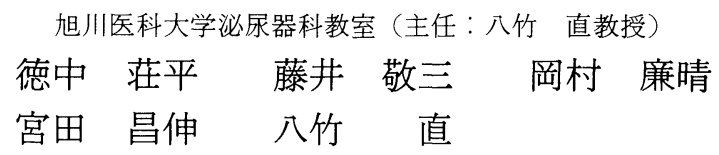

\section{BIOCHEMICAL ANALYSIS OF THE EXTERNAL URETHRAL SPHINCTER OF FEMALE RABBITS}

\author{
Sohei Tokunaka, Hiromitsu Fujii, Kiyoharu Okamura, Masanobu Miyata and Sunao Yachiku \\ Department of Urology, Asahikawa Medical College
}

The proportion of fast and slow myosin molecules in external urethral sphincter (EUS) was studied. The contents of fast and slow myosin light chains in EUS from 6 female rabbits (Japanese White, 6-month-old) were estimated using two-dimensional electrophoresis. The percentages of fast and slow myosin molecules were $54.5 \pm 14.9$ and $46.0 \pm 14.9$, respectively. It was thus shown that female rabbits EUS is composed of both fast and slow muscle fibers. The ratio of fast to slow myosins in female EUS was different from that in male EUS (fast myosin 90\%). These results implicate that female and male EUS would be functionally distinct.

Key words: external urethral sphincter, female rabbit, myosin

\begin{abstract}
要旨：6 力月齢の雌家鬼 6 頭から外尿道口ょり近位の外尿道括約筋 (external urethral sphincter： EUS）を採取し, 分離した筋肉から調製した試料を 2 次元電気泳動した。2 次元電気泳動ゲルから速筋 型軽鎖 2 と遅筋型軽鎖 2 のスポットを切出し, ピリジンで染色剂を溶出し, $605 \mathrm{~nm}$ における吸光度を測 定して試料内の速筋型ミオンンと遅筋型ミオシンの比率を算出した。その比率は速筋型 $54.0 \pm 14.9 \%$, 遅筋型 $46.0 \pm 14.9 \%$ であった。したがって雌 EUS も雄 EUS と同様に速筋型線維と遅筋型線維で構成さ

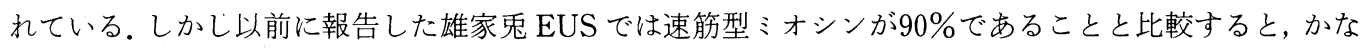
り異なり，雌 EUS では速筋型ミオンン，遅筋型ミオシンが合いなかばしている. 家鬼尿道は雌雄で形態 が全く異なるが, 速筋型, 遅筋型ミオシンの比率の分析でも雌雄間に違いが見られ, 機能的にも性差が あることが示唆された。 キーワード：外尿道括約筋, 雌家鬼, ミオンン
\end{abstract}

\section{緒 言}

外尿道括約筋（external urethral sphincter : EUS） は尿道の主要な括約筋機構であり骨格筋と同様に横紋 筋で構成される随意筋である。哺乳類の横紋筋を構成 する筋線維は収縮速度, ATPase 活性, 構成タンパク の違いにより，速筋線維と遅筋線維に大別出来る。あ る特定の骨格筋に打ける速筋線維と遅筇線維の構成比 率は同一動物種では多少の個体差はあるものの, ほ涪 一定であるとされている11.

過去の多くの電気生理学的研究では, 外尿道括約筋 は尿の禁制を持続的に保持する性質から大部分が遅筋 線維で構成される筋肉であると記載されて来た2，乙 かし, 我々は, 雄家鬼の外尿道括約筋の収縮タンパク,
ミオシンとATPase 染色による検討34) で雄家鬼の外 尿道括約筋では速筋線維比率が非常に高い（約 $90 \% ）$ ことを報告した。

今回, 外尿道括約筋の構成筋線維比率に性による違 いが存在するかどらか知るために雌家鬼の外尿道括約 筋の速筋型ミオンンと遅筋型ミオンンの比率を検討し た.

\section{対象と方法}

雌家鬼の泌尿生殖器の構造の模式図を図 1 に示す. 雌家鬼の泌尿生殖器は犬猫等の多くの哺乳動物之同様 に尿道が臸内に開口する。外尿道口が胵内にあり外尿 道口の遠位側では単一の管腔 vestibulum を形成し外 陰部における開口部は一つになっている5)。すなわち， 
図 1 雌家鬼の泌尿生殖器, 直腸の模式図. bl : bladder, $\mathrm{v}$ : vagina, vs : vestibulum, $\mathrm{r}$ : rectum.

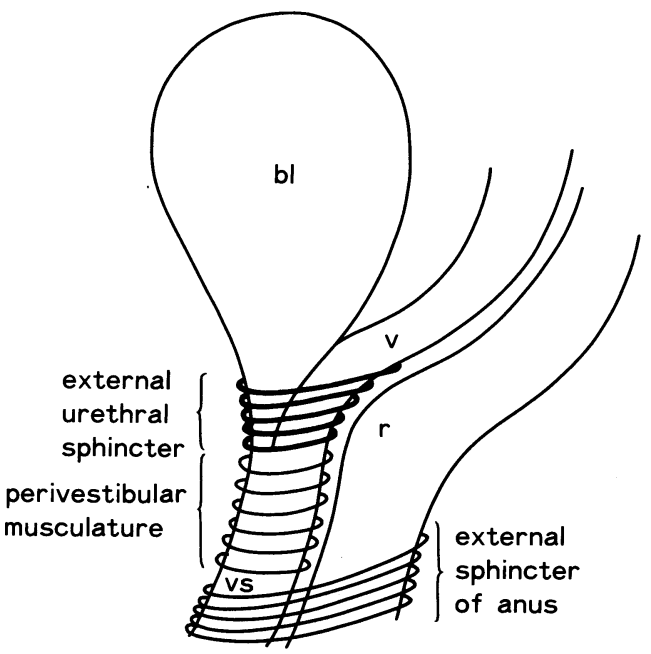

尿道と臸が完全に分離して外陰部に開ロするヒトや高 等霊長類の雌と大きく異なっていて, 胎生期の泌尿生 殖洞の形態を維持している.

雌家鬼のEUSは図 1 に描いたように膀胱頚部（尿 道）と䐋をいっしょに取囲む輪状筋で, 膀胼頝部（尿 道) と腔の間には EUS 筋線維は存在しない.つまり雌 家鬼では雄家鬼と異なり尿道のみを取囲むEUS は存 在せず，横紋筋性括約筋は尿道と䐋を取囲む urogenital sphincter とも言うべき構造をしている.

ヒト女性の横紋筋性尿道括約筋も男性のそれとは大

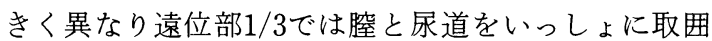
んでいる6)ことが知られているが, Gosling, J.A. ${ }^{7)}$ (尿 道周囲の骨盤底筋ではない尿道固有の横紋筋性括約筋 を男女の区別なく EUS と呼んでいる。

また男女の会陰部は胎生初期には区別がないが，男 性では精巣由来の dihydrotestosterone, Müllerian duct inhibiting hormone の作用で男性化し，女性では これらのホルモンを欠如するために女性化することが 知られている. 尿道固有の横紋筋性括約筋も男女で全 く同じ原器から分化して来たものが男性では前立腺や 尿道球腺の分化, 女性ではミューラー管由来の腔の分 化により最終的には形態的に大きく異なるようになる と考学られる。

以上の二つの理由から本論文では雌家鬼の尿道固有 の横紋筋性括約筋を雄家鬼のそれと同様に外尿道括約 筋（EUS）と呼ぶことにする.
尿道の臸への開口部以下の vestibulum の周囲にも 輪状筋構造があり図 1 では perivestibulal muscle: PVM とした. 従来の猫, 家鬼その他の雌動物の神経解 剖学的研究8)で, これら雌動物の EUS は胵に開口する 外尿道口より近位の部分にあることが分っている。し たがって PVM はヒト男子の前部尿道周囲の笳肉と同 様に尿の禁制には直接関与しない外陰部の筋肉と考え られる。

標本採取と 2 次元電気泳動用試料の調製：ネンブ タールを耳静脈より急速静注して屠殺した 6 頭の雌家 鬼（日本白色，体重 $2.4 \mathrm{~kg}$ ) から膀胼，vestibulum（泌 尿生殖洞), 腔を外院部, 直腸と一塊にして摘出した。 この摘出組織からさらに直腸と外陰部を切除して vestibulum と膀胼および腔の遠位部からなる標本を作成 してー $80^{\circ} \mathrm{C} て ゙$ 凍結した。

この凍結標本から尿道が臸に開口する外尿道口の部 位より近位の EUS 部分を0.3mm の厚さに横断薄切 して $50 \%$ グリセンン $50 \%$ リックスバッファー $(\mathrm{RB})^{3)}$ に浸けて $-20^{\circ} \mathrm{C} て ゙ 2$ 週間以上保存してグリセ リン化した。

既報3)のごとく実体顕微鏡を用いてグリセリン化し た組織から横紋筋のみを採取した。採取した横紋笳は ミリポアフィルターにのせて水分を可及的に取除いた 後，湿重量を測定した。採取筋組織は位相差顕微鏡で 横紋の観察をして横紋筋であることを確認した。採取 筋組織に 3 倍量のライシスバッファーを加えてミク口 ガラスホモジナイザーで室温でホモジナイズした後 $600 \times \mathrm{g}$ で10分間遠心して上清を 2 次元電気泳動用試 料とした。タンパク濃度は Bradford 法"9)で測定した。

2 次元電気泳動： 2 次元電気泳動は O'Farrell ${ }^{10)}$ に 準じて，1 次元目に当電点電気泳動， 2 次元目に SDS ポリアクリルアミドゲル電気泳動を行った。1 次元ゲ ルには $100 \mu \mathrm{g}$ の試料を注入した。 2 次元目の SDS-ポ リアクリルアミドゲルには分離ゲルのアクリルアミド 濃度15\%のものを使用した。電気泳動は既報3)の様に 行った。

速筋型ミオシン軽鎖と遅筋型ミオシン軽鎖の比率の

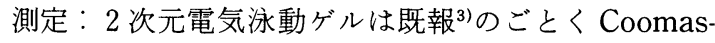
sie Brilliant Blue R で染色した脱染色した.このゲル から速筋型ミオシン軽鎖 $2 \mathrm{~F}$ のスポットと遅筋型ミオ シン軽鎖2Sのスポットを切出した. Fenner ${ }^{11)}$ の方法 に従って, 切出したゲル片からピリジン溶液で Coomassie Brilliant Blue Rを抽出し, ウシ血清アル ブミンを標準として $605 \mathrm{~nm}$ に打ける吸光度を測定し 
表 1 採取した外尿道括約筋 (EUS) の湿重量

\begin{tabular}{c|c}
\hline Rabbit No. & EUS $(\mathrm{g})$ \\
\hline 1 & 0.50 \\
2 & 0.30 \\
3 & 0.10 \\
4 & 0.30 \\
5 & 0.30 \\
6 & 0.50 \\
mean \pm 1sd & $0.33 \pm 0.14$ \\
\hline
\end{tabular}

表 2 外尿道括約筋 (EUS) における速筋型ミオンン 軽鎖2 (fast MLC2) と遅筋型軽鎖2 (slow MLC2) の割合

\begin{tabular}{c|c|c}
\hline Rabbit No. & fast MLC2(percent) & slow MLC2(percent) \\
\hline 1 & 68.7 & 31.3 \\
2 & 38.8 & 61.2 \\
3 & 36.7 & 63.3 \\
4 & 70.0 & 30.0 \\
5 & 67.5 & 32.5 \\
6 & 42.2 & 57.8 \\
mean \pm 1sd & $54.0 \pm 14.9$ & $46.0 \pm 14.9$ \\
\hline
\end{tabular}

てタンパク濃度を算出した。 1 つの試料について12枚 の 2 次元ゲルを作成し，それぞれのゲルについてミオ シン軽鎖 $2 \mathrm{~F}$ と $2 \mathrm{~S}$ の比率を算出した.

\section{結 果}

採取したEUSの湿重量を表 1 に示した。 6 頭の

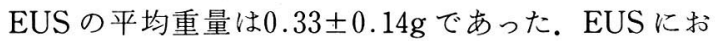
ける速筋型ミオンン軽鎖 $2 \mathrm{~F}$ と遅筋型ミオンン軽鎖 $2 \mathrm{~S}$ の比率を表 2 に示した。 $2 \mathrm{~F}$ と $2 \mathrm{~S}$ の比率は個体により かなりの差異が見られた。 $2 \mathrm{~F}$ と $2 \mathrm{~S}$ の比率の平均はそ れぞれ $54.0 \pm 14.0 \%$ と $46.0 \pm 14.0 \%$ であった。図2 2 は 表 2 の家鬼 No. 2の EUS の 2 次元電気泳動ゲルのミ オシン軽鎖領域の写真であるが，速筋型ミオンンと遅 筋型ミオンンはほぼ同量であり, 特に $2 \mathrm{~F}$ と $2 \mathrm{~S}$ の

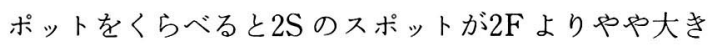
いことが分る。

\section{考察}

横紋筋線維は収縮速度や疲労性の違いなどで，速筋 線維と遅筋線維に大別される. 筇線維のタイプ分類に 打いてその簡便さと確実性で沉用されている ATPase 染色では, 成熟家鬼の横紋筋線維はタイプ 1 , タイプ2A, タイプ2Bの 3 種類に分類される ${ }^{12)}$. タ イプ1線維は, 疲労しにくい遅筋線維であり, タイプ $2 \mathrm{~A}$ とタイプ $2 \mathrm{~B}$ はともに速筇線維であるがタイプ $2 \mathrm{~A}$
図 2 EUS の 2 次元電気泳動ゲル, ミオンン軽鎖領 域. 表の No. 2 の家香. 速筋型ミオンン軽鎖 $(1 \mathrm{~F}+$ $2 \mathrm{~F}+3 \mathrm{~F})$ と遅筋型ミオンン軽鎖 $(1 \mathrm{~S}+1$ 'S $+2 \mathrm{~S})$ の スポットが汪同量であり, 特に $2 \mathrm{~F} と 2 \mathrm{~S}$ のスポッ トを比べる2Sがやや大きい。

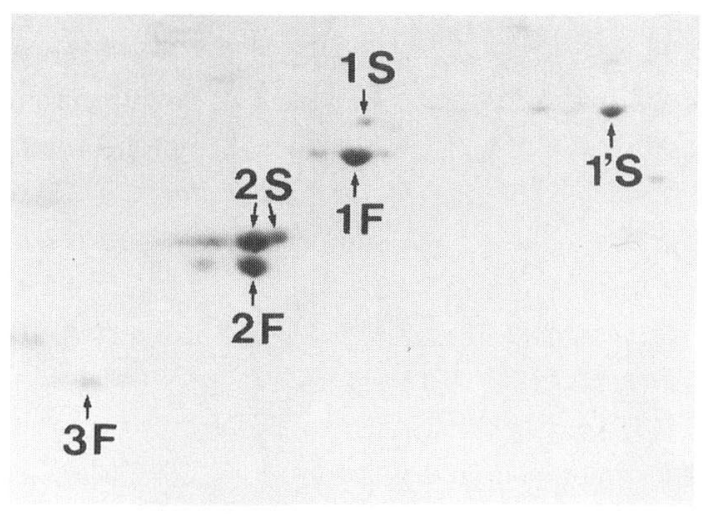

は, やや疲労しにくいのに対し,タイプ2B は, 易疲労 性である。

各種の電気泳動法による研究で, 速筋線維と遅筇線 維では ATPase 活性が違うだけでなく収縮タンパク， ミオンンも異なったアイソザイムを持つことが知られ ている13114)。また調節タンパク，トロポニンや，トロポ ミオンンにも速筋型, 遅筋型アイソザイムがある ${ }^{15) 16)}$.

ミオシン 1 分子は 2 本の重鎖と 4 本の軽鎖で構成さ れている。重鎖 ${ }^{177}$, 軽鎖 ${ }^{181199}$ にも速筋型, 遅筋型が知ら れている。遅筋線維タイプ 1 線維のミオシン軽鎖は, 1S, 1'S, 2S 33 種類があり, 速筋線維タイプ $2 \mathrm{~A}$ と2B の軽鎖は，1F，2F，3F の 3 種類が知られている。速筋 型でも遅筋型でもミオシン 1 分子にある 4 本の軽鎖の らち 2 本は必ず軽鎖 2 (DTNB 軽鎖) であることが 分っている18119). したがって, 本研究で行った様に, あ る試料中の速筋型ミオシンと遅筋型ミオシンの比率を 求めるためには軽鎖 $2 \mathrm{~F}$ と $2 \mathrm{~S}$ の比率を算出すればよい ことになる.

今回検討した雌家鬼 EUS ではかなりの個体差が あったが，平均すると速筋型ミオシン $54 \%$, 遅筋型ミ オシン $46 \%$ であった。

ヒトおよび動物の EUSを構成している筋線維タイ プの比率と分布についてはいくつかの研究があるが, 結果は色々で統一された見解は無い上うであ $3^{20) 231}$. 我々は, 以前に ATPase 染色を使って雄家鬼 のEUS がタイプ 1 線維, $13 \%$, タイプ $2 \mathrm{~A}$ 線維, $45 \%$, タイプ2B 線維, $42 \%$ で構成されることを報告した4). 
またミオシン軽鎖と末变性ミオシンの分析から雄家鬼 EUS 由来のミオンンは速筋型 $88 \%$, 遅筋型 $12 \%$ からな ることも報告した ${ }^{3)}$. したがって家鬼では, 雌の方が雄 より EUS の遅筋線維の比率が高くなっている.

横紋筋に普遍的に認められる法則としてサイズ原 則 ${ }^{24)}$ が知られている。個々の横紋筋は多数の筋線維で 構成されている。一つの運動神経細胞 (motoneuron) は複数の筋線維を支配して扔り, 同じ motoneuronに 支配されているこれら複数の筋線維はすべて同じ筋線 維型になっている. 支配 motoneuron と支配される筋 線維を合せて運動単位と言うが, ある動作を行らため の筋肉の収縮にどの運動単位が動員されるかは毎回変 るわけではなく, 運動単位の動員の順序は中枢神経系 に制御された機構によってきちんと決っている。この 機構は motoneuronの大きさ(サイズ), 興奮閾值, 神 経伝動速度により成立っている。

すなわち, 遅筋線維であるタイプ 1 線維と, 速筋線 維であるタイプ $2 \mathrm{~A}$ 線維, タイプ2B 線維の motoneuronはそれぞれ異なっている. タイプ 1 線維の支配 motoneuron が最も小さく興奮閾值も最も低く, 神経 伝動速度が最も遅くなっている.タイプ $2 \mathrm{~B}$ 線維の支配 motoneuron は最も大きく, 興奮閾值が最も高く, 神経 伝動速度が最もはやくなっている。タイプ $2 \mathrm{~A}$ 線維の 支配 motoneuron は前 2 者の中間の大きさで, 中間の 興奮閾值, 中間の神経伝動速度を持つ.

したがって, motoneuronに対する中枢からの刺激 が弱く, 筋の収縮強度が弱いときにはタイプ 1 線維の みが動員され, motoneuronに対する刺激が強まり, 収 縮の強度が増すにつれてタイプ2A, タイプ2B の順序 で動員される。これをサイズ原則と言っている。

EUS にこのサイズ原則を適用すると, 膀胱の蓄尿期 にはEUSの遅筋線維が弱い神経刺激で収縮を持続 し, 意識的な尿線の中断や腹圧の急激な上昇に起因す る膀脂内圧の変化など短時間の強い収縮が必要な時だ け強い神経刺激により速筋線維が収縮に参加すると考 えられる。

雌家鬼 EUS の速筋型, 遅筋型ミオンン比率は雄家 鬼のそれと大きく異なるので雌雄による排尿動態が異 なる可能性を示していると推定される.

雌家鬼と雄家鬼の EUS の解剖学的形態は大きく異 なっており, 雌家鬼EUSは雄のそれと異なって尿道 のみならず埶をも取囲んでいる。この理由は「対象と 方法」の項で述べたように, 雌雄で異なった外陰部, 会陰部分化が起こるために雌雄で同じ原器から分化し
たEUS が雌では胠の発生分化により, 雄では前立腺, 尿道球腺の発生分化によって影響を受け異なる形態と なるものと考光られる。しかし, 雌家鬼の vestibulum を雄家鬼の前部尿道に置き換えて考劣るならば，雌家 鬼の泌尿生殖器は雄家鬼のそれと同様に胎生期の泌尿 生殖洞の形態を残していると考兄られ, EUS も雌雄で 非常に似た形態をとっていると見ることも出来る.

成熟雄 EUS は成熟雌 EUSよりも筋量が多い。また 今回の実験で示されたように速筋型ミオシン, 遅筋型 ミオシンの構成比率も雌雄で異なってお抢り, 雄は雌よ り速筋型ミオンンの比率が高い。つまり, EUS は雌雄 により形態的にも機能的にも異なる性質を持つようで ある。この違いが何によっておこってくるのか興味が 持たれる.

雄ラットの球海綿体筋や, 陰茎根部の横紋筋は, 胎 児期に胎児の殬丸由来の androgen の影響を受けて発 達し, これらの筋肉を支配する motoneuron の発育に も androgen の存在が必要なことが知られている。一 方, 雌ラットでは, 球海綿体などを支配する motoneuron は胎生早期には雄ラットと同様に存在するが, androgen が無いためにその多くが消失して減少し, 球海 綿体筋は出生後数日で消隇する ${ }^{25)}$.

すなわち，一般の横紋筋と異なり球海綿体筋などの 会陰部の横紋筋は, 胎児期の androgenにより, 性差が 生ずるわけである。外尿道括約筋では, この様な現象 はまだ知られていないが，雌雄における著しい形態の 差は, 球海綿体筋と同様の機構により引き起こされる のではないかと想像される。

\section{結語}

雌家鬼 EUS の解剖学的構造は, 雄家鬼のそれとは かなり異なる。しかし雌家鬼の泌尿生殖器を雄家鬼の それと同様に胎生期の泌尿生殖洞の形態を残している と考光れば対応する位置に存在する相同の器官である と考えられた。

雌家鬼 EUS は雄家鬼 EUS 々同様に, 速筋線維と遅 筋線維の両方で構成されて抢り, 尿の禁制に必要な持 続的な収縮と短時間の強い収縮が共に可能な筋肉であ ることが示された.

雌家鬼 EUS ミオンンの速筋型, 遅筋型比率は雄家 鬼のそれとは異なることが確認された。したがって雌 雄の EUS は異なる性格をもつことが推定された。

\section{文 献}

1) Johnson, M.A., Polgar, J., Weightman, D. and Appleton, D. : Data on the distribution of fibre 
types in thirty-six human muscles, an autopsy. J. Neurol. Sci., 18, 111-129, 1973.

2) Mackel, R.: Segmental and descending control of the external urethral and anal sphincters in the cat. J. Physiol., 294, 105-122, 1979.

3) Tokunaka, S., Murakami, U., Okamura, K., Miyata, M. and Yachiku, S.: The fiber type of the rabbits' striated external urethral sphincter: Electrophoretic analysis of myosin. J. Urol., 135, 427-430, 1986.

4) 岡村廉晴, 徳中荘平, 宮田昌伸, 藤井敬三, 水永光 博, 橋本 博, 八竹 直: ヒストグラム解析による 雄家鬼外尿道括約筋の組織学的検討. 日泌尿会誌, 80, 1127-1133, 1989.

5) Cragie, E.H.: The urogenital system. in Bensley's Practical Anatomy of the Rabbit, Cragie, E.H., 8th. ed., p. 122, University of Tronto Press, Toronto, 1948.

6) Oelrich, T.M.: The striated urogenital sphincter muscle of the female. Anat. Rec., 205, 223-232, 1983.

7) Gosling, J.A., Dixon, J.S. and Humpherson, J. R.: Functional Anatomy of the Urinary Tract, 1st ed., p. 5.8, Gower Medical Publishing, London, New York, 1982.

8) Langley, J.N. and Anderson, H.K.: The innervation of the pelvic and adjoining viscera. Part VII Anatomical observations. J. Physiol., 20, 372-406, 1896.

9) Bradford, M.M.: A rapid and sensitive method for the quantitation of microgram quantities of proteins urilizing the principle of protein-dye binding. Anal. Biochem., 72, 248-254, 1976.

10) O'Farrell, P.H.: High resolution twodimentional electrophoresis of proteins. J. Biol. Chem., 250, 4007-4021, 1975.

11) Fenner, C., Traut, R.R., Mason, D.T. and Wikman-Coffelt, J. : Quantification of coomassie blue stained proteins in polyacrylamide gels based on analysis of eluted dye. Anal. Biochem., 63, 595-602, 1975.

12) Burke, R.E., Levine, D.N., Tsairis, P. and Zajac, F.E. III : Physiological types and histochemical profiles in motor units of the cat gastrocnemius. J. Physiol., 234, 723-748, 1973.

13) d'Albis, A. and Gratzer, W.B.: Electrophoretic examination of native myosin. F.E.B.S. Letters., 29, 292-296, 1973.

14) Fitzsimons, R.B. and Hoh, J.F.Y.: Isomyosins in human type 1 and type 2 skeletal muscle fibres. Biochem. J., 193, 229-233, 1981.
15) Moore, G.E., Briggs, M.M. and Schachat, F.H.: Patterns of troponin $\mathrm{T}$ expression in mammalian fast, slow and promiscuous muscle fibres. J. Muscle Res. Cell Motil., 8, 13-22, 1987.

16) Schachat, F.A., Bronson, D.D. and McDonald, O.B. : Heterogeneity of contractile proteins. A continuum of troponin-tropomyosin expression in mammalian skeletal muscle. J. Biol. Chem., 260, 1108-1113, 1985.

17) Carraro, U. and Catani, C.: A sensitive SDSPAGE method separating myosin heavy chain isoforms of rat skeletal muscles reveals the heterogeneous nature of the embryonic myosin. Biochem. Biophys. Res. Commun., 116, 793-802, 1983.

18) Lowey, S. and Risby, D.: Light chains from fast and slow muscle myosins. Nature (Lond.)., 278, 81-85, 1971.

19) Barton, P.J.R. and Buckingham, M.E.: The myosin alkali light chain proteins and their genes. Biochem. J., 231, 249-261, 1985.

20) Gosling, J.A., Dixon, J.S., Critchley, H.O.D. and Thompson, S.A.: A comparative study of the human external sphincter and periurethral levator ani muscles. Brit. J. Urol., 53, 35-41, 1981.

21) Schr $\phi$ der, H.D. and Reske-Nielsen, E. : Fiber type in the striated urethral and anal sphincters. Acta Neuropathol., 60, 278-292, 1983.

22) Bazeed, M.A., Thuroff, J.W., Schmidt, R.A. and Tanagho, E.A. : Histochemical study of urethral striated musculature in the dog. J. Urol., 128, 406-410, 1982.

23) Tokunaka, S., Okamura, K., Fujii, H. and Yachiku, S.: The proportions of fiber types in human external urethral sphincter: Electrophoretic analysis of myosin. Urol. Res., 18, $341-344,1990$.

24) Saltin, B. and Gollnick, P.D. : Skeletal muscle adaptability: Significance for metabolism and performance. in Handbook of Physiology, Sec. 10, Skeletal Muscle, Peachey, L.D., Adrian, R. H. and Geiger, S.R., 1st ed., Williams \& Wilkins, Baltimore, 1983.

25) Arnold, A.P. and Jordan, C.L.: Hormonal organization of neural circuits. in Frontiers in Neuroendocrinology, Vol. 10, Martini, L. and Ganong, W.F., p. 185, Raven Press Ltd., New York, 1988.

（1991年12月17日受理） 